\title{
The Sociocultural Function of Translation: A Study of Simin Daneshvar's Stories Sociocultural Aspects
}

\author{
Nazanin Maghami ${ }^{1}$ \& Bahloul Salmani ${ }^{1}$ \\ ${ }^{1}$ Department of Translation Studies, Tabriz Branch, Islamic Azad University, Tabriz, Iran \\ Correspondence: Bahloul Salmani, Department of Translation Studies, Tabriz Branch, Islamic Azad University, \\ Tabriz, Iran. E-mail: bsalmani@iaut.ac.ir
}

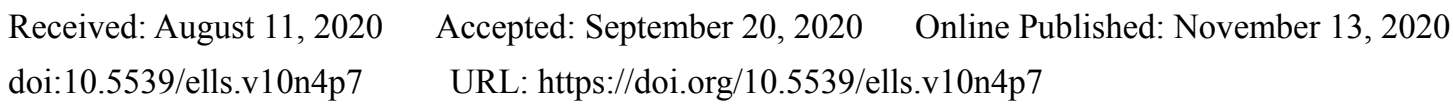

\begin{abstract}
The term "gender" is a load concept in translation studies. The present study focuses on stories written by Simin Daneshvar (1921-2012), a contemporary Iranian female translator and novelist, in order to explore how the visibility of women in the Iranian culture and community after a long patriarchal era has changed the community's thoughts about women. The method used for this study was qualitative with the interpretive approach. The corpus consisted of five Persian stories, Wandering Island, Wandering Cameleer, The Quenched Fire, Ask from Birds of Passenger and Suvashun by Daneshvar, who has contributed to the promotion of Iranian women's sociocultural status during the contemporary era. The results proved that women translators and novelists had endured the hardships of sociocultural changes and made it possible for the modern Iranian women to make themselves visible in their social context.
\end{abstract}

Keywords: gender, translation, culture, feminism, patriarchal community

\section{Introduction}

The term "woman" has the same meaning around the world. Any person from any stratum of the community can define the term "woman" as a human being who is biologically female. This definition is what all people around the world know about it, and also all dictionaries have defined it in the same way. However, there is a main question: What does "a woman" mean? The answer to this question may vary according to communities, citizens of the community, literacy level, culture, traditions, beliefs, religions, and all the factors which affect a human being's perspectives and the way they think. A woman is a creature biologically different from a man. However, being a woman is more than biology. It comes with the complexity of recognizing herself. Once recognized, she can do anything and everything. Unfortunately, women have mostly been identified as privileged, inferior, and weaker entities compared to men throughout the history. This is not what a woman chooses for herself since being inferior is a status in a patriarchal society, in which a man comfortably resides as a master and sets standards. As Steiner (1998) mentioned, "privileged" inferior is a concept shared by women and children, who have been minorities even if they outnumber men in their community (p. 39). This perspective or theory would remain in books and minds even if women proved themselves in all crucial fields of community.

Being an inferior part of the community is an evident issue most Iranian women have withstood during the past decades. However, translation was the most important factor which empowered women and let their voices be heard in the Iranian community since Qajar era and Tajmah Afagoldoleh was one of the pioneers. Also, as cited in Bai (2009), some scholars believe that translation is not an original task and it suffers from such problems as originality, authority, and creativity. However, translation has been considered as a tool to connect the worlds, cultures, ideologies, traditions, religions, and languages. Also, translation helps inferiors to be heard and become visible in a male-dominated society. As Harwood (1995) declared, "I feminist and translator am now responsible for who gets translated into my mother tongue, who and what becomes part of the cultural space I am co-authoring" (Harwood, 1995, p. 55).

Contemporarily, one of the figures who helped Iranian women to recognize themselves and get their identities and rights back in the patriarchal society of Iran was an Iranian translator, feminist, and novelist named, Simin Daneshvar (1921-2012). She was Born in Shiraz and passed away in Tehran, she wrote the enduringly popular suvashun, the first modern Persian-language novel written by a woman. Also she published a short story collection, Atashe Khamush (The Quenched Fire), the first such book by a woman to come out in Iran. She 
published a second collection, Shahri chon Behesht (A City as Paradise) before embarking on Suvashun. She was also known for her translations into Persian of such writers as Anton Chekhov and Nathaniel Hawthorne (Britannica).

As Bartky (1997) mentioned, every woman is not a feminist. Women who have been used to the patriarchal codes and have adjusted their lives to those codes may feel misidentified and lost, and may even feel "desexualized", or further, "annihilated" (Bartky, 1997, p. 146). Daneshvar lived in a patriarchal community and she is not a total feminist, but she has done her best by her writings and translations to break the stereotypes and go beyond the limits and help Iranian women get their identities. However, as cited in Bai (2009), a female translator is placed under double oppression: first, as a translator subject to the mastery of the original author or their text, then, as a woman translator subject to gender discrimination and male-regulated codes and norms (p. 10). The double oppression must certainly affect her epistemological strategy and positionality differently than male translators, but translation has helped Iranian women in all stages of their lives. Translation helps women to have financial independence, be more active in society, break the stereotypes, have their voice in the society, and be more visible and influential. Furthermore, translation has helped Iranian women prove that both sexes are equal, and they can be equal in the translation field, too.

This paper focuses on analyzing the Simin Daneshvar's stories and their implicit feministic meanings. This study adopts nine analytical issues of Nasrin Davoodnia (2016) to investigate how Simin Daneshvar's stories trying to change stereotypes about women and their attitudes toward their lives.

Principally, Simin Daneshvar's stories used as a case study to answer following question:

1) How a women novelist trying to change stereotypes about women attitudes and lives in her stories?

\section{Literature Review}

\subsection{Feminist Criticism}

Critics have already known through the notion of Culler (1983) that feminism is an act of reading as a woman. On the other hand, Yoder (1987) said that a feminist literary criticism does not mean to criticize women themselves or be a woman critic or even criticize a woman writer. Instead, it is about viewing the literary works with particular awareness and about the real correlation between the notion of gender and that of culture, literature, and life. Thus, gender is not the only factor that influences feminist literary works. Other factors can make differences such as the author, the reader, the character, society, culture, and religion, all of which influence the writing process (Algweirien, 2017, p. 121).

According to Bressler (1998), feminist criticism aims to change the degrading view of women so that all women will realize that they are not a "significant other", but each woman has her own identity and her essential role in the society. Bressler states that "as a social movement feminist criticism highlights the various ways women in particular have been oppressed, suppressed, and repressed. It asks new questions about old texts. It develops and uncovers a female tradition in writing. It analyzes women writers and their words from female perspectives" (Bressler, 1998, p. 185).

Both story writing and translation were significant ways for Iranian women to found their identities, become active in the community, and have a profession besides being a mother and wife. The idea that women only need to be a housewife and there is no need to be active in society shows the situation which women suffered in the past decades in Iran. Von Flotow (2012) has mentioned that superstition, religion, and tradition pervade the discourses of many of the female characters, who end up conveying and standing for values and perspectives which are detrimental to themselves and other women. Iranian story writers and translators, like Simin Daneshvar, by criticizing helped many women to find their ways and identities by their feministic stands. Although Daneshvar had a feministic point of view, she was against western feminism. Feminism in the Iranian literature has the same function as western countries because Iranian writers were mostly influenced by western feminism. They mostly had the perspective that women should be superior. However, Daneshvar is against extremist and radical feminism. She believed that this kind of feminism overwhelms men's rights and makes family nature precarious and can make the relation of women and men inscrutable (Daqiqi, 2002, p. 9).

\subsection{Translation and Culture}

We know that a nation's culture flourishes by interacting with other cultures. Cultural variety opens our eyes to human rights, but cultural variety can only be recognized through discussions. Generally, Language is an expression of culture and individuality of its speakers. It influences the way the speakers perceive the world. So focusing on the issue of translation from one language to another, the culture of both languages in the process of translation is influential. Of course, one should consider that to what extent the culture is in the text and to what 
extent the language is in culture (Akbari, 2013, p. 13).

Wittgenstein once said, "The limits of my language are the limits of my world" (1958, p. 53). Language, as a part of the cultural core, is at the heart of culture. What people do with language narrative, poetry, songs, plays, etc. are soft expressions of a culture; they are faces of culture. Languages are systems of verbal symbols, vocal and/or written, organized by particular rules (grammar) \& used by particular rules (grammar) and used by particular communities in order to develop and communicate their thoughts and affections (Akbari, 2013, p. 13).

\subsection{Review of Researches on Feminism and Culture}

So many thesis and papers worked on gender, translation and socio-cultural field. Some of foregoing studies which were done by Monireh Akbari (2013), Farzaneh Farahzad (2016), Bijan Bateni (2013), Bahram Moghaddas (2013), are mostly focuses on gender studies, culture and translation. They mostly interested in feminist movements took place by translators and women. Farzaneh Farahzad (2016) focused on role of women translators and novelist in contemporary Iran. Bijan Bateni (2013) also studied the Persian literary translation texts of female translators under the influence of feminist movements. Eventually, Bahram Moghaddas (2013) investigate the effect of gender in translation accuracy of Iranian English translators.

\section{Methodology}

This study is of qualitative type with an interpretive approach. Denzin and Lincoln (2000) claim that qualitative research involves an interpretive and naturalistic approach. According to them, "qualitative researchers study things in their natural settings, attempting to make sense of, or to interpret, phenomena in terms of the meanings people bring to them" (Denzin \& Lincoln, 2000, p. 3). The data of current study were gathered from five novels

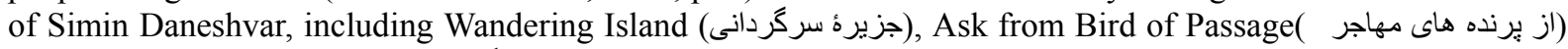

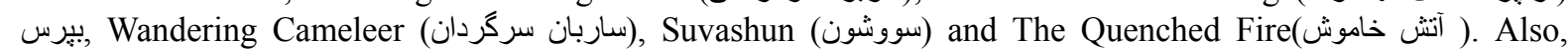
Nasrin Davoodnia's (2016) nine issues about Simin Daneshvar's Stories investigated in this study. This research focuses on the role and image of Iranian women throughout the years in different contexts. In results and discussion part, some selected texts chosen from mentioned books investigated by their explicit and implicit meaning and each text translated to English by researcher. Also, the selected texts embrace nine issues of Nasrin Davoodnia (2016) about hidden ideological and feministic thoughts behind Simin Daneshvar's stories. Eventually, each part consists of discussion part which is about investigation of researcher about the different points and sides of stories and their meanings.

\section{Discussions}

\subsection{Analysis}

Daneshvar has tried to help Iranian women to find their position and rights in the community as a woman without using any opposition for the patriarchal part of the community. She has tried to find a way to make equality between men and women. By using her writing skills, she made women be aware of their position in the Iranian community and try to get their rights and freedom. According to Daneshvar, the most critical social problem in Iran for women is their status, which is the result of the superstitions of a patriarchal community. She has showed femininity, passion, and household chores and community in a male dominate Persian literature (Ghobadi, 2004, p. 2). Most of the female characters are represented as heroes in Daneshvar's stories. She has tried to change the perspective of Iranian literature and make women be heard and visible through using dialogues which show women and men characters are not in a superior position, but they are two equal entities who complete each other. According to Nasrin Davoodnia (2016), Simin Daneshvar has focused on nine issues in her writings all of which refer to the Iranian society. In this study, we are going to investigate all these nine issues and elaborate on them via providing their English translations as follows:

\subsubsection{Forced Marriage}

Forced marriage is an issue that happens in a patriarchal community. Daneshvar is against this kind of marriage. For example, one of the forced marriages is the marriage between cousins, which was very popular in the Iranian community for a long time. In the past, some families never asked their children's ideas about marriage; in such cases, parents, especially fathers, decided about to whom their children should marry when they reach marriage age. They made such decisions sometimes even before the birth of their children, and the children had to obey their families' decisions due to sociocultural norms. The text has been taken from Ask from Bird of Passage (p. 93). 


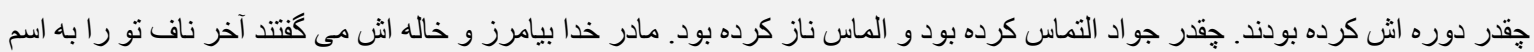

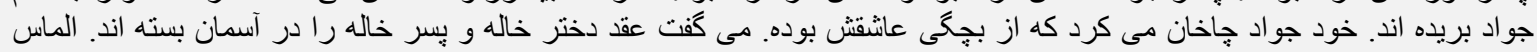

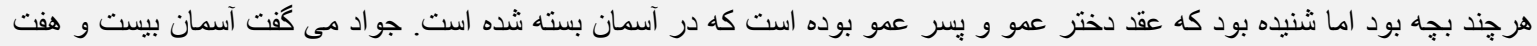

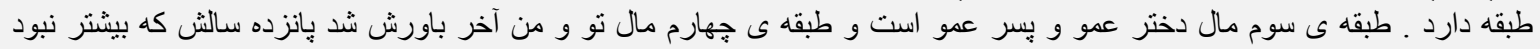

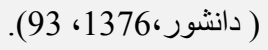

They all surrounded her. Javad begged, and she smirked. Her beloved mother and her aunt told her you were the chosen one for Javad. Javad was bluffing that he loved her since childhood. He believed that cousin's wedding was bound in the sky. Although Almas was young, she heard that this was cousins' (paternal) wedding which was bound in the sky. Javad told her that the sky has twenty-seven layers. The third layer is for cousins (paternal), and the fourth layer is for you and me. Finally, she believed, because she was just fifteen (Translated by researcher).

Simin daneshvar mostly tries to show patriarchal culture and community in her stories and some unusual cultures which are not logical. In Ask from the Birds of Passage Daneshvar indicates forced marriage. Most of the girls forced to get married in the young age and although the female character of story is fifteen but she accepted to marry her paternal cousin because of her parent's force also because of her lack of experience. So, the only intention of Daneshvar is to show her opposition to the forced marriage in a young age while she tries to let Iranian women be aware of their power and position in their lives.

\subsubsection{Polygyny}

Polygyny, as a well-criticized issue in feministic studies, has been covered by Daneshvar in her writings, too. However, the fascinating thing is that the polygyny does not refer to the status and modernity of a man. All men from every stratum of the community can have several wives. The male character of the Wandering Island is an open-minded and educated young man who has a pregnant wife, but he still thinks about marrying another woman. The text has been taken from Wandering Cameleer (p. 126).

$$
\text { (دليم: بر ايتان آيارتمان ميخرم. مادر بزركتان را هم بياوريد بهلوى خودتان. نيكو يك برهى سر به راه است. حتى هوو را تحمل خو اهد كرد }
$$

Salim: I will buy you a flat. You can also have your grandmother right beside you. Nikoo is an obedient woman, and she will bear a co-wife (Translated by researcher).

Simin Daneshvar indicates that even having a pregnant wife can't change the way men think. In Wandering Cameleer and Wandering Island Daneshvar demonstrates that although Salim's wife is pregnant and she jailed but he thinks of having another wife so he thinks even if my wife came out of jail, I can have two wives, on top of that Salim's father also getting married several times while he has a wife too. Eventually all men have a same excuse, they say that we are Muslim men so having several wives is Halal. This is one of the aspects which hurts Iranian women pride a lot. Insomuch, Morad the male character of Wandering Island says to his mother that, the only problem is you yourselves, so, if you want try not to get married a man who already has a wife. So in this point Daneshvar tries to change women point of view by giving some feministic points in stories.

\subsubsection{The Contrast between Modernism and Stereotypes}

The contrast between modernism and stereotypes is another issue that Daneshvar has mentioned in her stories. There are two types of women in the Wandering Island, traditional ones like mothers, grandmothers, and modern ones like daughters. However, there is one fundamental principle: a woman should always obey a man (father/husband/brother). A woman should obey her husband and fulfill her husband's and children's demands. The text has been taken from Wandering Cameleer (p. 39).

$$
\begin{aligned}
& \text { نيكو نمونه ى زن سنتى در اير ان و در مقابل سيمين است. زنى كه فقط ساخته شده براى شو هردارى. زنى كه "دستور شوهردارى را هر }
\end{aligned}
$$

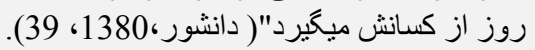


Nikoo is a traditional Iranian woman and she is totally different from Simin. She is created to be a housewife. A woman who learns to be a housewife from others (Translated by researcher).

Obedience, this is what an Iranian woman should have, even, the way her husband or her father think is wrong. She should obey them without asking question or without any opposition. This is what questioned Iranian women liberty, independence and self-respect throughout the years. Iranian women are demonstrating as a loyal creature who they live selfless and in a way that they don't have any need or wish and they just created to obey a man and live the way he wants. One of the best methods Daneshvar uses in her stories is making contradiction between characters. In Wandering Island, she makes an obvious contradiction between two female characters Nikoo and Simin. Nikoo showed as an independent woman who tries to live her life the way she wants but on the other side Simin is an obedient woman who lives her life the way her family and her husband want. But at the end all of them suffers from their husbands and intentionally or unintentionally they should obey their men.

\subsubsection{Negative and Destructive Stereotypical Manners}

According to Daneshvar, most of Iranian women have several negative and destructive stereotypical manners, including having passion for gold and jewelry, lying, back-biting, being fit and loving makeup, jealousy and eavesdropping, offensive language and insulting, trickery, and keeping up with the Joneses. Daneshvar sharply criticized all such issues in women. The text has been taken from Wandering Cameleer (p. 17).

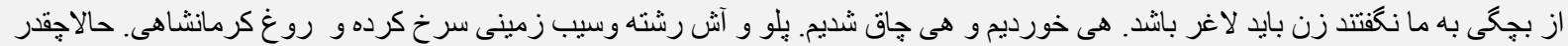

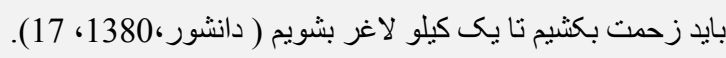

When we were young, our parents did not teach us how to keep fit. So we were eating a lot, and we were gaining lots of weight. We ate rice, vegetable soup, French fries and Kermanshah's oil; and now we should try hard to lose just a kilo of weight (Translated by researcher).

The text has been taken from Wandering Cameleer (p. 9).

$$
\text { مانشان عشى 1380، 9.آهته كفت كه خدا كند به دل احمد برات شود و بابت نفعش يك تكه جواهر براى من بردارد. حتى به زمرد هم قانعم ( }
$$

Mother Ashi whispered that "I hope Ahmad buys me a jewel just for his own profit. I'm even satisfied with Emerald" (Translated by researcher).

The text has been taken from Wandering Cameleer (p. 295)

هستى در ماجر اى مادرش آنقدر دروغ سر هم كرده بود كه حتى حقيقت و اقعه از باد خودش رفته بود ( دانشور ،1380، 295).

Hasti lied a lot about the mishap of her mother, and finally, she forgot the truth (Translated by researcher).

Although Daneshvar sharply criticized negative and destructive stereotypical manners in Iranian women but not all of them. Like Hasti in Wandering Island who doesn't like these manners. Besides, Daneshvar also gives a reason for these manners to show her respect to women too. She mentioned it in a dialogue that women obeyed, suffered, lied and eavesdropped in a patriarchal community because they don't have any access to the tough world of men. So, she shows that even if they have destructive stereotypical manners but there is a hidden reason behind it.

\subsubsection{Understatement of Love}

Understatement of love and censoring feminine feelings are some traditional problems Iranian women have encountered in the last centuries. Expressing their love and passion was considered taboo in the Iranian women's point of view, and they were thinking about it as their duty. Ignoring personal feelings and doing what the 
husband says is considered as an advantage for her. This is why Iranian women have always lived under their men's shadow. Eventually, who is the most important, are men. The Iranian wife never opens up her feelings to her husband, and she considers this manner as a modesty. The text has been taken from The Quenched Fire (1948, p. 50).

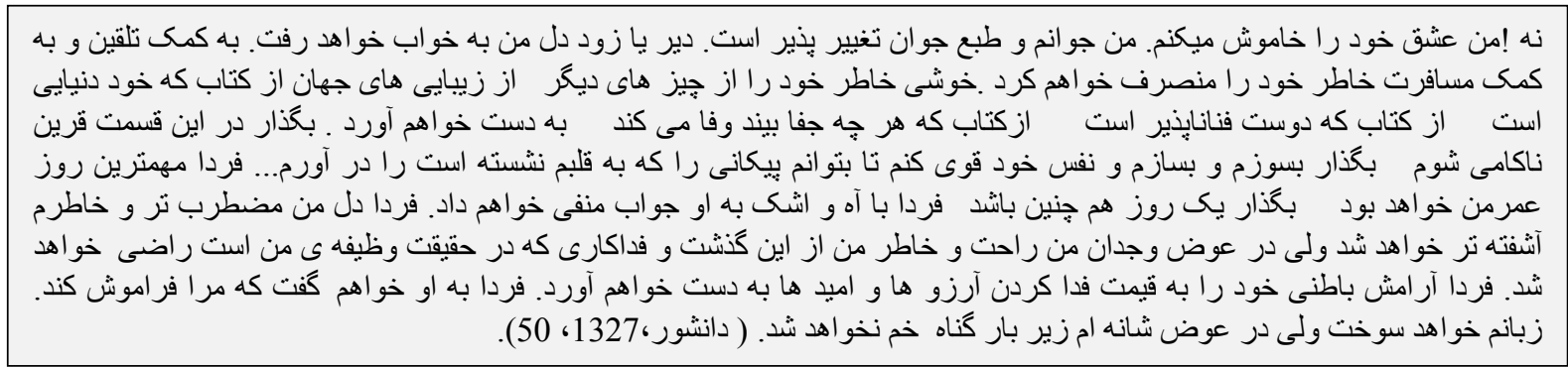

No! I will let go of this love. I'm young and flexible. Soon, I will forget about everything. As I inculcate and travel, I will discourage myself. I will find happiness in books which are immortal and loyal friends. Let me be sorrowful, let me grin and bear it and make myself stronger, so I can take this arrow out of my heart. Tomorrow will be an important day of my life; so, let it be. With sigh and tears, I will reject him. Tomorrow, I will be more scattered and more confounded. But I will have a clean conscience, and I will be satisfied because of the selflessness of self-devotion which is my duty. Tomorrow I will reach an inner peace by sacrificing my wishes and hopes. Tomorrow I will tell him to forget me. It will hurt me, but I won't feel guilty (Translated by researcher).

Daneshvar Tries to show that Iranian women can’t show their feelings even if this feeling is their Passione, love or its their anger, dissatisfaction. The only one who can show their feelings freely are men. And if a woman wants to be considered as a good wife should not show her feelings even if she suffers a lot. So, Daneshvar mostly wants to go beyond this limitation and let women to know that expressing their feeling is not a taboo and their value is not depending on concealing their thoughts and emotions.

\subsubsection{Discovering Yourself}

Beyond all the negative sides, Iranian women have positive aspects, too. One of the positive aspects of Iranian women is discovering themselves. As time passed, Iranian women lost their identity, and they did not have any duty unless, being a housewife, hostess, mother, and wife. In the contemporary Iran, although Iranian women have a profession, they have tried to search their identity in the Iranian patriarchal community. Before and after Iran's constitutional revolution, women did not have any right to participate in social and political issues. Even, they did not have the right to vote and they were living behind barriers. As Iranian women tried to find their identity, they tried to overcome the marginalized position and live in the center of the Iranian community. Moreover, Iranian contemporary women story writers tried to find their identity and prove that they could be an active member of their community and country.

In Wandering Island, Hasti tried to make herself visible by painting and taking part in political activities. She helped Morad and his friends and went to the city of Halabi Abad. Also, she was jailed. She did all of them because she wanted to show that she existed. The text has been taken from Wandering Island (2001, p. 114).

$$
\text { جنانجه خود ميكو ييد:به حفظ هويت زنانه و در عين حال مشاركت در اجتماع و استقلال مالى عقيده دارم ( دانشور، 1380، 114). }
$$

As she said: I believed in preserving feminine identity and at the same time participating in community and having financial independence (Translated by researcher).

In Wandering cameleer, Eshrat, who is spending time just for debauchery, at the end of the story, she wants to be changed. The text has been taken from Wandering Cameleer (2001, p. 294).

$$
\text { عشرت: آبجى من به شما يناه آوردم تا مر ا هم مثل هستى آدم بكنيد( دانشور ، 1380، 294). }
$$


Sister, I'm here to ask you to discipline me like Hasti (Translated by researcher).

Zari, the woman character in Suvashun, is the hero of the story. At first, she was a traditional woman who depended on her husband and children. She was a housewife, mother, and hostess. She has sacrificed her wishes because of her family. When her husband died, she became a fearless woman because there was not any reason for fear. Moreover, she wanted to get her feminine identity back. The text has been taken from Savushun (2001, p. 252).

ميخو استم بجهه هايم را با محبت و در محيط آرام بزرگ كنم. اما حالا با كينه بزرگ ميكنم. به دست خسرو تفنى ميدهم ( دانشور، 1380؛

I wanted to raise my children with love in a tranquil setting but know I will raise them with loathing. I will give Khosrow a gun (Translated by researcher).

What Daneshvar does is to add some heroic women characters in her stories too. What heroic women means to her is the one who tries to be independent and tries to get her right back from patriarchal community and men. In Wandering Island Hasti tries to make herself visible by her paintings and her iconoclasm acts, even if these actions make her to be jailed. And Zari character in savushun shows that an obedient and dependent woman can be disobedient and independent and she won't need any man to continue her life. Being Independent is one of the factors which Daneshvar tries to show to Iranian women and make them to be aware of their feminine power.

\subsubsection{Financial Independency}

Another positive aspect about Iranian women is their endeavor to have financial independence. According to feminist studies, the need for money is one of the reasons that women live under the dominance of men. In a patriarchal community, financial independence for woman is not accepted. Mostly, men want to be in the center of everything, and they want women to depend on them. Working outside the home seems a frightening idea to men because they think they will lose their wives. In the Wandering Island, the male character tries to impose his ideas on the female character and tries to force her to accept his ideas. The text has been taken from Wandering Island (2001, p. 41).

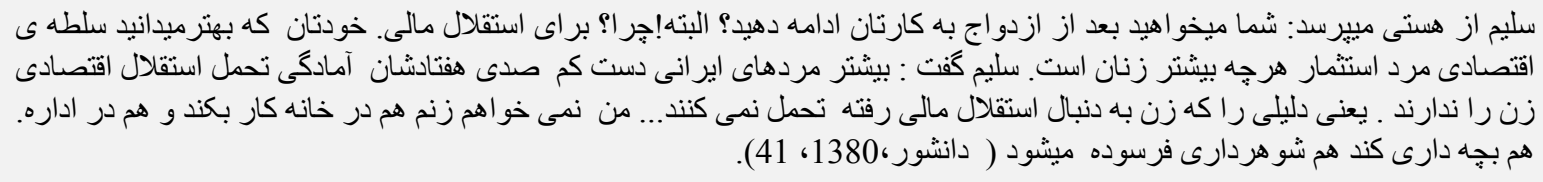

Salim to Hasti: Do you want to continue your job after marriage? Of course! Why not? For financial independence. You know better, men's financial dominance is for the exploitation of women. Salim said: most of the Iranian men, for example, seventy percent of them are not ready for the financial independence of women. They can't tolerate the reason why a woman wants financial independency. I don't want my wife to work both at home and at the office. She will burn out if she looks after children and her husband (Translated by researcher).

Financially dependent, this is what men wants from their wives. In patriarchal community women should completely be dependent mostly financially because they all know that if a woman become financially independent they never obey a man. So, Daneshvar show this aspect in Wandering Island that the male character who wants an obedient wife tries to impose his ideas in a way that the female character doesn't find out his real intention. Daneshvar clearly shows that men try to make women privileged by taking their rights and dependence from them.

\subsubsection{Motherhood}

Mother and child relationship is another positive side of a woman in Daneshvar's stories. One of the best feelings and experiences in the world for a woman is to become a mother. This feeling completes a woman. Both traditional and modern Iranian women want to have a family and experience the motherhood. The woman 
character of Daneshvar's story, Hasti, loves another man and she proposed him, but Morad did not accept her proposal, and because she wants

to have family and a baby, she married another man named Salim. Hasti did not know Salim and did not have any feelings for him. The text has been taken from Wandering cameleer (2001, p. 253).

بجه در شكم هستى ميلوليد. هنتى داغ ميشد. انحار سركرم بزركترين عثق بازى هاى جهان است ( دانشور ،1380، 253).

Baby moved in her womb. She feels strange. It seems like she experiences the world's biggest love story (Translated by researcher).

Becoming a mother and having a baby is a feeling which, every woman wants to experience its considered as an innate feeling but as it showed in Wandering Cameleer this could be a foible for women. Although female character of story loves another man but for having a child she prefers to marry another man that she doesn't know about him because she thinks that being in late 20 s is late to get married and have a baby.

\subsubsection{Dreaming}

Dreaming is another element in Daneshvar's stories. The dreams which come true. Female characters dream a lot in the storyline, but at the end, all dreams come true, and something happens in their lives. In Wandering Island, Hasti is suffering from depression and she becomes a wanderer in her dreams; this dream is predicting the Iran-Iraq war. Also, in Suvashun, Zari saw her husband's death in her dreams.

In a nutshell, Daneshvar has tried to show a patriarchal community and locate the position of Iranian women in her stories. By using feministic points, she wanted to let Iranian women find their identity and status in the Iranian society and live in the center of it and overcome subaltern status. However, she was against western feminism, and tried to use a compatible feministic point in her stories because she was aware of the Iranian real social situation. Daneshvar, because of Savak (intelligence service in Iran during Pahlavi dynasty), did not have any permission to work outside. So, instead of hiding herself behind the walls, she let her voice be heard by her translations and writings. She tried to prove that women can do anything like a man does. A man can do feminine works, too. She has mentioned that women should not bear to be a wife, mother, and hostess, but they should participate in governmental and community issues, too. Daneshvar's professional life and her endeavors have proved that she has managed to find a way to make her voice audible.

\section{Conclusion}

The history of translation and story writing in Iran shows that Iranian women translators and story writers have fought over revolutions, wars, jobless days, superstitions, culture, and so many hardships. They have tried to be active in the Iranian society. The Iranian women have proved that they could be a woman, mother, and wife at the same time. They have shown that they could be active both in society and at home. Translation and story writing not only allows women's voices to be heard across the borders and cultures but also have had an immense impact on the improvement of their living standards. As Daneshvar has shown in her stories and translations, women themselves can change the way they live if they change their attitudes and perspectives. They can be at the center of the Iranian society instead of being marginalized. The Iranian women translators and story writers like Daneshvar have done their best to lead Iranian women and help them to find their identities and status in the male-oriented society of Iran. Being a woman is more than a biological identity. It comes with the complexity of recognizing themselves. Once recognized, she can do anything and everything.

\section{References}

Akbarian, M. (2013). The Role of Culture in Translation. Journal of Academic and Applied Studies, 3(8), 13-21. Retrieved from http://www.academians.org

Bartky, S. (1997). Foucault, Femininity and The Modernization of patriarchal Power. In D. Meyers (Ed.), Feminist Social Thought (pp. 92-111). London: Routledge.

Daneshvar, S. (1948). Extinguished Fire (Atashe Khamoosh). Tehran: Aliakbar va Shorakaa.

Daneshvar, S. (1997). Ask From Birds Of Passage (Az Parandeh haye Mohajer Bepors). Tehran: Kanoon.

Daneshvar, S. (2001a). Suvushun (15th ed.). Tehran: Kharazmi.

Daneshvar, S. (2001b). Wanderer Cameleer (Sarebane Sarghardan, 1st ed.). Tehran: Kharazmi. 
Daneshvar, S. (2001c). Wandering Island (Jazireyeh Sargardani). Tehran: Kharazmi.

Daqiqi, M. (2002). Wandering Island is Communal (Sargardani Yek Jazirehye Hameghani Ast). Zanan, 32-33.

Davoodnia, N. (2016). Study of Feministic Perspectives and Their Effect on Simin Daneshvar's stories (Barasiye Didgahe Zanmadarane Va Baztabe An Dar Asare Simin Daneshvar). Journal of Woman and Culture, 121-134.

Denzin, N., \& Lincoln, Y. (Eds.). (2000). Handbook of Qualitative Research. London: Sage Publication Inc.

Ghobadi, H. (2004). Analysis of Suvashun According to Schools of Literature and Social Discourse (Tahlile Daroonmayeh Haye Suvashun Az Nazare Maktabhaye Adabi Va Ghoftemanhaye Ejtemaei). Research in Persian Language \& Literature, 41-54.

Lotbiniere-Harwood, S. (1995). Geographies of Why. In S. Simon (Ed.), Culture In Transit. Montreal: Vehicule.

Steiner, G. (1975). After Babel. Uk: Oxford University Press.

Von Flotow, L. (2012). Translating Women: From Recent Histories and Re-Translations to Queeying Translation and Metramorphosis. Quaderns: Revista De Traduccio, 127-139.

Wittgenstein, L. (1958). The Blue and Brown Books. Oxford: Blackwell.

\section{Copyrights}

Copyright for this article is retained by the author, with first publication rights granted to the journal.

This is an open-access article distributed under the terms and conditions of the Creative Commons Attribution license (http://creativecommons.org/licenses/by/4.0/). 